\title{
HARVESTING AND WOOD TRANSPORT PLANNING WITH SNAP III PROGRAM (Scheduling and Network Analysis Program) IN A PINE PLANTATION IN SOUTHEAST BRAZIL ${ }^{1}$
}

\author{
Eduardo da Silva Lopes², Carlos Cardoso Machado³, Amaury Paulo de Souza ${ }^{3}$ and Carlos Antonio Alvares \\ Soares Ribeiro ${ }^{3}$
}

\begin{abstract}
The objective of this study was to verify the potential of SNAP III (Scheduling and Network Analysis Program) as a support tool for harvesting and wood transport planning in Brazil harvesting subsystem definition and establishment of a compatible route were assessed. Initially, machine operational and production costs were determined in seven subsystems for the study area, and quality indexes, construction and maintenance costs of forest roads were obtained and used as SNAP III program input data. The results showed, that three categories of forest road occurrence were observed in the study area: main, secondary and tertiary which, based on quality index, allowed a medium vehicle speed of about 41,30 and $24 \mathrm{~km} /$ hours and a construction cost of about US\$ 5,084.30, US\$ 2,275.28 and US\$ $1,650.00 / \mathrm{km}$, respectively. The SNAP III program used as a support tool for the planning, was found to have a high potential tool in the harvesting and wood transport planning. The program was capable of defining efficiently, the harvesting subsystem on technical and economical basis, the best wood transport route and the forest road to be used in each period of the horizon planning.
\end{abstract}

Key words: Harvesting, wood transport, planning and SNAP III program.

\section{PLANEJAMENTO DE COLHEITA E TRANSPORTE DE MADEIRA USANDO O PROGRAMA SNAP III (Scheduling and Network Analysis Program) EM UMA PLANTAÇÃO DE PINUS NO SUDESTE DO BRASIL}

\begin{abstract}
RESUMO - O objetivo deste trabalho foi verificar a aplicabilidade do programa SNAP III (Scheduling and Network Analysis Program) como ferramenta de apoio no planejamento da colheita e do transporte florestal em condições brasileiras. Os aspectos avaliados foram a definição dos subsistemas de colheita e a determinação de uma rota compativel de transporte de madeira. Inicialmente, determinou-se o custo operacional e de produção das máquinas em sete subsistemas de colheita tecnicamente viáveis para a região de estudo, como também os índices de qualidade e de custos de construção e manutenção de estradas, os quais foram utilizados como dados de entrada no SNAP III. Posteriormente, verificou-se, através de um estudo de caso, a aplicabilidade do programa como ferramenta de apoio no planejamento da colheita e do transporte. De acordo com os resultados, constatouse que há três categorias de estradas de ocorrência na área de estudo: principal, secundária e terciária, as quais, com base no índice de qualidade encontrado, permitiram uma velocidade média do veículo de transporte de 41,0 30,3 e 24,3 km/hora e um custo de construção de US\$ 5.084,30, US\$2.275,28 e US\$1.650,00/km, respectivamente. Quanto ao uso do SNAP III como ferramenta de apoio ao planejamento, o sistema mostrou-se com elevado potencial, podendo auxiliar no planejamento da colheita e do transporte. O programa foi capaz de definir com eficiência os subsistemas de colheita técnica e economicamente viável, a rota ótima de transporte e as estradas em uso em cada período do horizonte de planejamento.
\end{abstract}

Palavras-chave: Colheita, transporte, planejamento e SNAP III.

1 Recebido para publicação em 12.2.2003.

Aceito para publicação em 4.11.2003.

2 Professor da UNICENTRO e ex-bolsista da FAPEMIG e CNPq. ${ }^{3}$ Professor do Departamento de Engenharia Florestal da Universidade Federal de Viçosa - UFV, 36570-000 Viçosa-MG. 


\section{INTRODUCTION}

Wood harvesting is a very important activity within the forestry sector responsible for much of the final product cost and for many complex technical, economic, environmental and ergonomic factors which dynamically influence the operation. Thus planning has become essential to identify and control adverse developments beforehand. According to Machado (1984), planning is the most important step during harvest, as it combines all the possible systems and methods, recognizing the restrictions and ordering the available resources. Santos (1995) states that planning is adaptation to local conditions, an operations system that allows maximum use of machinery, increases productivity and reduces operational costs.

For an efficient forest harvest it is essential to obtain improved quality, minimize environmental impacts, increase yield and reduce operational cost by using scientific planning methodology. Presently, only some Operational and Research and Geographic Information Systems (GIS) techniques have been used as support tools in solving some specific problems. However, computer systems are the most efficient planning alternatives Since Operation, Geographic Information System and Information Technology are used, many variables can be simultaneously controlled.

Several programs used as tools in forestry planning were developed based on linear programming models (Clutter et al., 1992), such as the Timber RAM (Resource Allocation Model) developed for the USDA Forest Service and used in forest harvest program and the FORPLAN (Forest Planning) developed from Timber RAM, an important forest planning program in the United States. Other programs are currently available, including Implan, Magis, Spectrum, Teams, Stals-3 (Thompson, 1997) and Forplan (Johnson \& Stidart, 1987). However, the most outstanding program is SNAP III (Scheduling and Network Analysis Program), developed by Professor John Sessions of Oregon State University, in partnership with the USDA Forest Service (Sessions \& Sessions, 1992). SNAP III is a computer program used in harvest and transport planning which considers harvest systems, roads and transport, silvicultural treatments, land and water fauna adjacency restriction, economic analyses etc.

The main objectives of this study were to verify, through a case study, the applicability of the SNAP III program as a planning tool for forest harvest and transport

R. Árvore, Viçosa-MG, v.27, n.6, p.831-836, 2003 under Brazilian conditions, and to define technically and economically viable harvest subsystems and a compatible route for wood transport.

\section{MATERIAL AND METHODS}

\subsection{Study Region}

This study was carried out with data from Duratex S. A., a Brazilian company that produces cut wood for Pallets, MDF and Flooring, situated in Agudos, São Paulo. The region is located between $22^{\circ} 15^{\prime}$ and $22^{\circ} 30^{\prime} \mathrm{S}$ and $48^{\circ} 00^{\prime} \mathrm{W}$. The mean altitude is $550 \mathrm{~m}$ with predominantly flat relief, CWA climate, mesothermic with dry winter and rainy summer, mean annual temperature of $21.9^{\circ} \mathrm{C}$ and mean monthly precipitation of $123 \mathrm{~mm}$. The forest areas are composed of Pinus caribaea hondulensis and Pinus oocarpa, with a mean yield of $360 \mathrm{~m}^{3} /$ ha. Clear cut at 12 years of age is the management system adopted.

\subsection{Computer System Used}

SNAP III (Scheduling and Network Analysis Program), 3.19 version, was used as a support tool in forest harvest and transport planning. In this study, the most technically and economically suitable subsystems in each period were planned by analysis of the operational costs, maximum economic distance from extraction and qualitative and cost road analyses. Transport planning aimed to determine a compatible transport route by qualitative analyses of road costs.

\subsection{Data Survey}

Data was obtained from polygons, harvest and roads of the study area, where SNAP III program, was applied.

\subsubsection{Polygons and Roads}

Polygon data were obtained from digital maps and electronic spreadsheets, which contemplated identification, area, age volume and species. Road data included identification, width, grade, horizontal geometry and type of covering on the rolling track.

\subsubsection{Forest harvest}

To supply reliable planning information, operational cost and machine production were estimated in seven 
technically potential harvest subsystems for the studied region, as well as the maximum economic extraction distance, as shown in Table 1.

Table 1 - Forest harvesting systems studied Quadro 1 - Subsistemas de colheita florestal estudados

\begin{tabular}{|c|c|c|}
\hline $\begin{array}{c}\text { Harvest } \\
\text { Subsystem }\end{array}$ & Machines & Operation \\
\hline \multirow{2}{*}{1} & Harvester CAT $320 \mathrm{BL}$ & Felling and processing \\
\hline & Forwarder $6 \mathrm{X} 6-14 \mathrm{t}$ & Extraction \\
\hline \multirow{2}{*}{2} & Slingshot CAT $320 \mathrm{BL}$ & Felling and processing \\
\hline & Forwarder $6 \mathrm{X} 6-14 \mathrm{t}$ & Extraction \\
\hline \multirow{2}{*}{3} & Harvester TJ 2628 & Felling and processing \\
\hline & Forwarder $6 \mathrm{X} 6-14 \mathrm{t}$ & Extraction \\
\hline \multirow{2}{*}{4} & Slingshot CAT $320 \mathrm{BL}$ & Felling and processing \\
\hline & Timber Hauler A25 & Extraction \\
\hline \multirow{2}{*}{5} & Harvester CAT $320 \mathrm{BL}$ & Felling and processing \\
\hline & Timber Hauler A25 & Extraction \\
\hline \multirow{2}{*}{6} & Harvester TJ 2628 & Felling and processing \\
\hline & Timber Hauler A25 & Extraction \\
\hline \multirow{3}{*}{7} & Feller-buncher CAT320 BL & Felling \\
\hline & Skidder CAT 525 & Extraction \\
\hline & Slingshot CAT $320 \mathrm{BL}$ & Processing \\
\hline
\end{tabular}

The operational cost was calculated by the accounting method, which uses estimated and real values in the methodology by Miyata (1980), along with maintenance and staff payment costs used by MOREIRA (2000) and administration cost by Valverde (1995).

\subsubsection{Transport and Forest Roads}

Transport was planned by analyses of road networks. For this, the quality and cost attributes in each road category found in the study area were obtained: First Class Road (double lane with first class surface/covering), Second Class Road (two lane without metaling) and Third Class Road (single lane without finishing).

The quality attribute was the operational speed performance of the transport vehicle, whose values were obtained by using the TransRoad program, developed by Machado (1991). Road construction costs were estimated by summing the costs of the activities involved in the construction, i.e., topographic survey, cleaning and leveling; draining and paving, while the maintenance costs were obtained by information from the market.

\subsection{SNAP III Processing and Data Entry}

Polygon and road data were entered in SNAP III program from digital maps supplied by the company, in the CAD Microstation SE. Since data should be entered in SNAP III from the Geographic Information System ArcInfo UNIX, they were previously converted to ArcInfo NT (8.01 version) for database editing and construction. The maps were then converted for the SNAP III program by Arc2SNAP, which composed of AMLs (ArcInfo programming language) and programs in $\mathrm{C}$ developed to ease the transfer the coverings of lines, polygons and the ArcoInfo UNIX attribute into the SNAP III format. Cost data on harvest and road subsystems, silvicultural treatments and demand were entered directly in to SNAP III using specific editors.

\subsection{SNAP III Application - Case Study}

The SNAP III program was used in this study as a planning tool in the study area considering the following situation:

- Annual wood consumption: $35,680 \mathrm{~m}^{3}$ of solid wood with bark;

- Planning horizon: 12 years;

- Silvicultural treatment: clear cut;

- Maximum opening size in the harvest areas: 100 hectares.

\section{RESULTS AND DISCUSSION}

\subsection{Forest Harvest}

Table 2 shows the total costs of the different harvest subsystems studied. Costs were similar among subsystems 1, 2 and 7, and subsystems 3, 4 and 5. Only subsystem 6 had very high costs, due to the operational cost of the Timberjack harvester and the VOLVO timber hauler.

The maximum economic extraction distances for the machines in each one of the studied subsystems are shown. The forwarder and the skidder showed the least extraction distance, while the timber hauler showed the greatest extraction distance, since in this situation, extraction and main transport are simultaneously performed by the timber hauler.

R. Árvore, Viçosa-MG, v.27, n.6, p.831-836, 2003 
Table 2 - Forest harvest subsystem costs

Quadro 2 - Custos dos subsistemas de colheita florestal

\begin{tabular}{|c|c|c|c|c|}
\hline \multirow{2}{*}{ Subsystems } & \multicolumn{3}{|c|}{ Operations } & \multirow{2}{*}{$\begin{array}{c}\text { Total Costs } \\
\left(\mathrm{US} \$ / \mathrm{m}^{3}\right)\end{array}$} \\
\hline & Felling/Processing & Extraction & Processing & \\
\hline 1 & 1.83 & 1.42 & - & 3.25 \\
\hline 2 & 1.67 & 1.42 & - & 3.09 \\
\hline 3 & 3.38 & 1.42 & - & 4.80 \\
\hline 4 & 1.67 & 2.89 & - & 4.56 \\
\hline 5 & 1.83 & 2.89 & - & 4.72 \\
\hline 6 & 3.38 & 2.89 & - & 6.27 \\
\hline 7 & 0.64 & 1.16 & 1.33 & 3.13 \\
\hline
\end{tabular}

\subsection{Forest Roads}

\subsubsection{Quality Attributes}

Table 4 shows road class with the respective transport vehicle speed for the three road categories in the study area, with values being later applied to all the road segments within each category for analysis.

The forest road first class category has an excelent horizontal geometry, double line and very good surface; the forest road second class category has a good horizontal geometry, double line and very good surface; the forest road third class category has a poor horizontal geometry, single line and poor surface. The results show that the mean vehicle speed decreased proportionally with the quality standard of the roads, influenced the performance of the vehicles and contributed to an increase in transport costs.

\subsubsection{Forest Road Construction and Maintenance Costs}

The construction costs were estimated for the three forest road categories found in the study area based on the activities and market information: construction and maintenance cost, respectively, first class (US $\$ 5,084.30$ / $\mathrm{km}$ and US\$1,404.50); second class (US\$2,275.28 and US\$ 842.70) and third class (US\$ $1,650.00$ and US\$ 280.90). These values were later applied to all the road segments within each category for analysis.

The main roads show higher construction and maintenance costs due to better construction standard, high traffic volume of heavy and extra-heavy vehicles

R. Árvore, Viçosa-MG, v.27, n.6, p.831-836, 2003 and the need to be open to traffic throughout the year. On the other hand, the third class roads presented a lower cost due to their inferior construction standard and reduced traffic volume, requiring repairs only at critical points during the raning season.

\subsection{Case Study using the SNAP III Program}

\subsubsection{Forest Harvest}

The following data were considered to define the technically and economically viable harvest subsystems in each period: timber deposit localization, harvest costs, maximum economic extraction distances and road quality and cost parameters. The polygons to be harvested were defined along with their respective points of timber deposition and harvest subsystems, as illustrated in Figure 1. Observing this example, knots 6512,6527 and 6530 were selected as possible timber deposit points in polygon 19 , while subsystems 1,2 and 3 were defined by the programs as being technically viable.

After defining the technically viable harvest subsystems, the programs defined the one with the lowest cost. Table 3 shows the harvest subsystems defined by the program with the respective harvested volume and area worked in each period of the planning horizon. As it can be observed, the subsystems varied among the periods, but subsystems 2 (Slingshot + Forwarder) and 4 (Slingshot and Timber Hauler) were outstanding and chosen in all the periods. Subsystem 2 was selected because of its lower operational cost and technical viability for use in the smaller polygons due to its lower extraction distance. Subsystem 4 was more frequently 


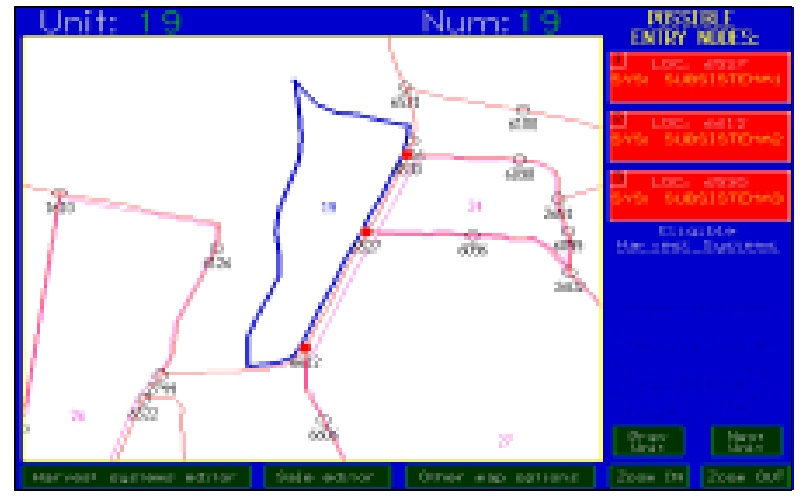

Figure 1 - Wood deposit localization in Polygon 19.

Figura 1 - Local ização dos depósitos demadeira do pol ígono 19.

Table 3 - Forest harvest subsystems defined by SNAP III program

Quadro 3 - Subsistemas de colheita florestal definidos pelo programa SNAP III

\begin{tabular}{|c|c|c|c|}
\hline Period & $\begin{array}{c}\text { Harvest } \\
\text { Subsystems }\end{array}$ & Area & Volume \\
\hline \multicolumn{2}{|c|}{$\left(\mathrm{n}^{\circ}\right)$} & (ha) & $\left(\mathrm{m}^{3}\right)$ \\
\hline \multirow{4}{*}{1} & 1 & 694.6 & $5,668.7$ \\
\hline & 2 & $1,457.5$ & $9,034.1$ \\
\hline & 4 & 585.8 & $10,834.8$ \\
\hline & 7 & 151.3 & 889.7 \\
\hline \multirow{2}{*}{2} & 2 & 17.4 & 75.5 \\
\hline & 4 & $1,244.1$ & $26,285.7$ \\
\hline \multirow{3}{*}{3} & 1 & 0.7 & 9.4 \\
\hline & 2 & 4,6 & 7.1 \\
\hline & 4 & $1,080.3$ & $26,380.1$ \\
\hline \multirow{2}{*}{4} & 2 & 2.0 & 18.9 \\
\hline & 4 & 603.1 & $26,368.3$ \\
\hline \multirow{2}{*}{5} & 2 & 7.9 & 23.6 \\
\hline & 4 & 607.9 & $26,396.6$ \\
\hline \multirow{2}{*}{6} & 2 & 0.7 & 16.5 \\
\hline & 4 & 514.1 & $26,391.9$ \\
\hline 7 & 4 & 385.9 & $26,380.1$ \\
\hline \multirow{3}{*}{8} & 1 & 1.0 & 11.8 \\
\hline & 2 & 2.2 & 9.4 \\
\hline & 4 & 563.8 & $26,408.4$ \\
\hline \multirow{3}{*}{9} & 2 & 0.4 & 11.8 \\
\hline & 4 & 433.8 & $17,829.8$ \\
\hline & 5 & 57.0 & $8,543.2$ \\
\hline \multirow{3}{*}{10} & 2 & 2.1 & 18.9 \\
\hline & 4 & 392.8 & $22,021.2$ \\
\hline & 5 & 40.4 & $\begin{array}{r}4,387.2 \\
\end{array}$ \\
\hline \multirow{4}{*}{11} & 1 & 0.9 & 14.2 \\
\hline & 2 & 7.3 & 61.4 \\
\hline & 4 & 780.4 & $23,567.0$ \\
\hline & 5 & 89.7 & $2,695.1$ \\
\hline \multirow{4}{*}{12} & 2 & 6.8 & 226.6 \\
\hline & 4 & 407.9 & $24,284.4$ \\
\hline & 5 & 64.1 & $1,852.6$ \\
\hline & 7 & 1.7 & 30.7 \\
\hline
\end{tabular}

used because of its lower operational cost among those with greater extraction distance, being, therefore, viable for extraction from large polygons.

It should be pointed out that this information is important in operational planning decision making such as: defining and dimensioning felling teams, machines and equipment, allocation support teams; machine yield estimates, control process etc. Figure 2 shows part of the report on the harvested polygons and the roads in use during the first four periods of the planning horizon. This information was very important in harvest and transport planning, as it enables the allocation of machines and vehicles, felling team yields, machines, and equipment to predict transport vehicle performance and construction, conservation and assessment costs of the existing roads.

\section{CONCLUSIONS}

SNAP III program showed high potential as a support tool in harvesting and wood transport planning under Brazilian conditions.

SNAP III program was technically and economically efficient in defining harvest subsystems, helping in decisions such as: definition and dimensioning of the felling teams, machines and equipment; yield estimates, control process etc.

SNAP III program allowed to determine a compatible transport route and the extension of roads in use, an important information in transport planning, since it allows to predict transport vehicle performance, make decisions on conservation of existing roads, displacement of service personnel, machines and vehicles.

\section{REFERENCES BIBLIOGRAFIC}

CLUTTER, J. L. et al. Timber management: a quantitative approach. New York: Wiley, 1992. 333 p.

JOHNSON, K. N.; STUART, T. W. FORPLAN

version 2: mathematical programmer's guide. [S.1.: s.n.], 1987.

MACHADO, C. C. Planejamento e controle de custos na exploração florestal. Viçosa: Universidade Federal de Viçosa, 1984. 138 p.

MACHADO, C. C. TransRoad. Viçosa: Universidade Federal de Viçosa, 1991. (s.d).

R. Árvore, Viçosa-MG, v.27, n.6, p.831-836, 2003 
MIYATA, E. S. Determining fixed and operating costs of logging equipament. [S.1.]: USDA Forest Service, 1980. 16 p. (General Technical Report, NC-55).

MOREIRA, F. M. T. Análise técnica e econômica de subsistemas de colheita de madeira de eucalipto em terceira rotação. 2000. $148 \mathrm{f}$. Dissertação (Mestrado em Ciência Florestal) - Universidade Federal de Viçosa, Viçosa, 2000.

SANTOS, S. L. M. Alocação ótima de máquinas na colheita de madeira. 1995. 99 f. Dissertação (Mestrado em Ciência Florestal) - Universidade Federal de Viçosa, Viçosa, 1995.
SESSIONS, J.; SESSIONS, J. B. Scheduling and network analysis program: user's guide. [ S.1.: s.n.t.], 1992.

THOMPSON, T. L. Decision support systems for ecosystem management: an evaluation of existing systems. In: Rocky moutain research station. Fort Collins: Colorado, 1997. p. 118-122.

VALVERDE, S. R. Análise técnica e econômica do sistema de colheita de árvores inteiras em povoamentos de eucalipto. 1995. 123 f. Dissertação (Mestrado em Ciência Florestal) - Universidade Federal de Viçosa, Viçosa, 1995. 